\title{
Anti-inflammatory and anti-allergic activities of Skipjack tuna (Katsuwonus pelamis) dark muscle hydrolysates evaluated in cell culture model
}

\author{
Worrapanit Chansuwan $^{1}$, Chutha Takahashi Upunqui ${ }^{1}$, Pavinee Chinachoti ${ }^{2}$ \\ ${ }^{1}$ Interdisciplinary Graduate School of Nutraceutical and Functional Food, $9^{\text {th }}$ Floor Learning \\ Resources Center (Square building), Prince of Songkla University, Hatyai, Songkhla 90112, \\ Thailand. ${ }^{2}$ Quest Ltd. 2/1 Soi Areesampun 11 Rama 6 Rd Payathai, Bangkok 10400, Thailand.
}

Corresponding author: Pavinee Chinachoti, PhD, Prof. Quest Ltd. 2/1 Soi Areesampun 11 Rama 6 Rd Payathai, Bangkok 10400, Thailand

Submission Date: April $1^{\text {st }}$, 2019. Acceptance Date: July $28^{\text {th }}$, 2019. Publication Date: July $31^{\text {st }}, 2019$.

Citation: Chansuwan W., Upunqui C.T., Chinachoti P. Anti-inflammatory and anti-allergic activities of Skipjack tuna (Katsuwonus pelamis) dark muscle hydrolysates evaluated in cell culture model. Functional Foods in Health and Disease 2019; 9(7): 446-465. DOI: https://doi.org/10.31989/ffhd.v9i7.618

\begin{abstract}
Background: Oxidative stress and inflammation are inextricably linked and play major roles in the onset and development of Non-communicable diseases (NCD) which are the most common cause of death and disability in modern world. Hydrolyzed proteins have also been suggested to be used to manage adverse food allergic reaction. Therefore, this study aimed to investigate antiinflammatory and anti-allergy activities of dark muscle tuna hydrolysates using biological cell line systems as a function of enzyme, the extent of hydrolysis and molecular weight range.
\end{abstract}

Methods: Dark muscle tuna hydrolysates were prepared with two different enzyme types; Alcalase and Flavourzyme. Anti-inflammation activity was measured by inhibitory effect of nitric oxide (NO) production on lipopolysaccharide (LPS)-stimulated RAW 264.7 macrophage cells. Anti-allergy was determined from ability of hydrolysates to inhibit $\beta$-hexsosaminidase $(\beta$ HEX) release from RBL-2H3 mast cells. Cytotoxicity was also investigated in both RAW 264.7 macrophage cells and RBL-2H3 mast cells.

Results: No cytotoxic effect on RAW 264.7 macrophage cells and RBL-2H3 mast cells was observed. The NO inhibition and $\beta$-HEX release were found significant in dose dependent manner $(\mathrm{p}<0.05)$. Alcalase hydrolysates demonstrated greater anti-inflammatory and anti-allergic activities than Flavourzyme hydrolysates $(\mathrm{p}<0.05)$. $\mathrm{IC}_{50}$ of both effects were lower than the 
unhydrolyzed control, $>45.44 \mu \mathrm{g} / \mathrm{ml}$ for NO inhibition and $>65.23 \mu \mathrm{g} / \mathrm{ml}$ for $\beta$-HEX release inhibition. These effects increased with the extent of hydrolysis and enzyme concentration. The peptide of lowest molecular weight range $(<3 \mathrm{KDa})$ was highest in anti-inflammatory and antiallergic actions. Reducing secretion of TNF- $\alpha$, IL-6 and IL-1 $\beta$ was found greater in Alcalase hydrolysate than Flavourzyme one.

Conclusions: Skipjack tuna dark muscle hydrolysates from Alcalase resulted in peptides with anti-inflammation activity, as determined by NO production in LPS-stimulated RAW 264.7 macrophage cells and anti-allergic properties as measured by a suppression of degranulation of sensitized RBL-2H3 cells. Anti-inflammatory effect may be due to their anti-oxidative capacity and relevant inflammatory factors attenuated with hydrolysate by reducing secretion of proinflammatory cytokine (TNF- $\alpha$, IL-6 and IL-1 $\beta$ ). Inhibition of $\beta$-HEX release by peptides may be due to membrane-stabilizing action or/and blockade of $\operatorname{IgE}$ antibody at fragment region.

Keywords: Skipjack tuna, anti-inflammation, enzymatic hydrolysate, dark muscle, anti-allergy

\section{INTRODUCTION}

Oxidative stress and inflammation are inextricably linked and play major roles in the onset and development of Non-communicable diseases (NCD) which are the commonest cause of death and disability in modern world. Inflammation is a normal protective response to tissue injury caused by physical trauma, allergen, noxious chemicals or microbiological agents [1] in order to inactivate or destroy trauma factors and to set stage for tissue repair [2]. Immune activated macrophages cell secretes nitric oxide (NO) at inflammatory sites for tissue repair in response to the inflammation stimuli [3] but overproduction of NO could lead to or link with various inflammatory diseases. Therefore, inhibiting NO production is an interesting strategy for therapeutic intervention in inflammation disorders [4].

Immune function in aged humans and animals can be modulated by antioxidants which are shown to enhance immune response [5]. However, this area can be controversial because not all antioxidants are equally effective. Therefore, optimal levels of antioxidant needed for immunological enhancement or maintenance may vary not only with antioxidants but also with life-stage (i.e., children, adult, and elderly). Effects of antioxidants are expected to benefit among aged human and animals rather than younger ones, respectively, to the different oxidative stress or sensitivity to oxidative stress of older individuals [5]. Based on literature search, there have been several reports on fish protein hydrolysates that exhibit significant increases in in-vitro antioxidative properties such as free radical scavenging and reducing power [6-10]. In our earlier work, dark muscle tuna (Skipjack) hydrolysate has been shown to exhibit antioxidative properties with increasing degree of hydrolysis using Alcalase and Flavourzyme [11]. Hydrolyzed proteins have been suggested to be used to manage adverse food allergic reaction in human and in pets [12-17]. This relies on protein hydrolysis creating a wide range of peptides with a small size so that they are not recognized as antigen, therefore, rendering non- or hypoallergic properties. Pork, chicken and milk are common protein sources already have been utilized in hydrolysate-based products. However, very limited fish hydrolysate research has 
focused on immunological benefits that are related to inflammation which is the common precursor of an array of aging disease such as cardiovascular, diabetes, arthritis, brain (Alzheimer and Parkinson's) and rheumatoid arthritis [5]. Fish and fish by-products have been demonstrated to be potential candidates for making value-added anti-inflammation such as protein hydrolysate from sweetfish [18], salmon by-product [19], and salmon [20]. However, limited research has focused on tuna by-products particularly dark meat which can be obtained in abundance from tuna processing lines.

Skipjack (Katsuwonus pelamis) is the commercially highest species caught accounting for $50.7 \%$ of the global total [21] and used primary in canned tuna production. In canning process, by-products (mostly skin, bone, dark meat, and viscera) of such production include $70 \%$ of the original fish materials [22] with dark muscle contributing up to at least $48 \%$ of total meat [23] which is approximately yield to over 0.5 million tons by the early 2000 s with increasing tendency every year [21]. Tuna-by products could potentially be used as alternative source to produce fish hydrolysates that are good source of protein (17-20\%) and rich in essential amino acids [10, 24-25]. Therefore, in this present study, the anti-inflammatory and anti-allergy effects of dark muscle tuna hydrolysates was investigated using biological cell line systems as a function of enzyme, the extent of hydrolysis and molecular weight range. This current research is potentially beneficial for further utilization of valuable proteins from tuna that may not be fully used for value-added applications.

\section{MATERIALS AND METHODS}

\section{Materials}

Dark muscle of Skipjack tuna was kindly donated from Songkla Canning Public Co., Ltd. (Songkhla, Thailand). In the tuna canning process, whole tuna was cooked by steaming at $100^{\circ} \mathrm{C}$ for 30 min after which the skin was scraped off by hand. The dark muscle was then separated from the steamed meat and then packed in polyethylene bags and transferred on ice to university laboratory within $1 \mathrm{~h}$. Upon arrival, foreign materials such as bone, scale, etc. were removed manually and then vacuum-sealed and stored at $-20^{\circ} \mathrm{C}$ until used.

\section{Chemicals and Reagents}

Alcalase $^{\circledR} 2.4 \mathrm{~L}(2.4 \mathrm{AU} / \mathrm{kg}$, density of $1.18 \mathrm{~g} / \mathrm{ml})$, an endoproteinase from Bacillus licheniformis, and Flavourzyme (1000 LAPU/kg, density of $1.27 \mathrm{~g} / \mathrm{ml})$ an exoproteinase from Aspergillus oryzae were purchased from Sigma-Aldrich (St. Louis, MO, USA). Minimum essential medium eagle (MEM), anti-DNP IgE (Monoclonal Anti-DNP), Lipopolysaccharide (LPS, from Escherichia coli), RPMI-1640 medium, 3-(4,5-dimethyl-2-thiazolyl)-2,5-diphenyl-2Htetrazolium bromide (MTT), 1-nitroarginine (1-NA), were purchased from Sigma; fetal calf serum (FCS) was from Gibco. All chemicals used in the experiments were of analytical grade.

\section{Cell culture}

Anti-inflammatory activity was determined by the inhibition ability of tuna dark muscle hydrolysates against NO production in LPS-stimulated RAW 264.7 macrophage cell. The murine macrophage cells (RAW264.7) were purchased from American Type Culture Collection (ATCC) 
and cultured in RPMI-1640 medium supplemented with $0.1 \%$ sodium bicarbonate and $2 \mathrm{mM}$ glutamine, penicillin G (100 units/ml), streptomycin $(100 \mu \mathrm{g} / \mathrm{ml})$ and 10\% FCS. The cells were incubated at $37{ }^{\circ} \mathrm{C}$ in $5 \% \mathrm{CO}_{2} /$ air.

Anti-allergy as the inhibitory $\beta$-hexosaminidase $(\beta$-HEX) secretion of dark muscle tuna hydrolysates was investigated using rat mast cell line RBL-2H3 cells. The RBL-2H3 cells were purchased from American Type Culture Collection (ATCC) and cultured in MEM containing $10 \%$ FCS, penicillin (100 units/ml), streptomycin (100 units $/ \mathrm{ml})$, and 15\% FCS. The cells were incubated at $37{ }^{\circ} \mathrm{C}$ in $5 \% \mathrm{CO}_{2} /$ air.

\section{Enzymatic hydrolysis}

To prepare hydrolysates, frozen tuna by-products were thawed overnight at $4{ }^{\circ} \mathrm{C}$. The thawed samples were washed twice with deionized water $\left(55^{\circ} \mathrm{C}\right)$. The quantity of water used for washing was 1:3 (sample: water). The slurry was agitated for $5 \mathrm{~min}$. Water was decanted through muslin cloth and samples were allowed to drain for $10 \mathrm{~min}$. Washed samples were minced (particle size $\leq 0.5 \mathrm{~mm}$ ) using a grinder (Moulinex Charlotte HV3, France). One hundred of the resulting ground tuna dark muscle paste was continually mixed with deionized water at a ratio of 1:2 (W/V) and homogenized at a speed of 13,000 rpm for 1 min using IKA Labortechnik homogenizer (Selangor, Malaysia). The $\mathrm{pH}$ of homogenates was adjusted to corresponding optimal $\mathrm{pH}$ for each enzyme(i.e., 8.5 for Alcalase and 7.0 for Flavourzyme), using $6 \mathrm{~N} \mathrm{NaOH}$. The mixtures were then incubated at $55^{\circ} \mathrm{C}$ (Alcalase) or $50^{\circ} \mathrm{C}$ (Flavouzyme) for 20 min prior to enzymatic hydrolysis. The enzymatic hydrolysis was started when different amounts of enzymes at $0.5,1,2$, and $4 \% \mathrm{w} / \mathrm{w}$ (protein basis) were added. Hydrolysis was carried out for 0, 30, 60, 90, 120,180 , and $240 \mathrm{~min}$ when the reaction was stopped by heating at $95^{\circ} \mathrm{C}$ for $15 \mathrm{~min}$ in a water bath with occasional agitation.

All samples were cooled immediately in ice and the $\mathrm{pH}$ 's of the sample were subsequently adjusted to 7.0 using $1 \mathrm{M} \mathrm{HCl}$ (if needed). These were then filtered through muslin cloth 3 times and supernatants collected. The supernatant was then freeze-dried using Christ Delta 2-24 LSC Freeze dryer (Christ, Osterode, Germany) at 0.055 mbar for $12 \mathrm{hr}$. The freeze-dried hydrolysates were packed in amber bottles with $\mathrm{N}_{2}$ gas flush and kept at $-20^{\circ} \mathrm{C}$ until use.

\section{Fractionation by Ultrafiltration (UF) membranes}

Hydrolysates were fractionated using Amicon ${ }^{\circledR}$ concentrator equipped with UF membrane (Millipore, USA) with molecular weight cut off (MWCO) of 30, 10 and $3 \mathrm{kDa}$ to isolate four fractions $(>30 \mathrm{kDa}, 30-10 \mathrm{kDa}, 10-3 \mathrm{kDa}$, and $<3 \mathrm{kDa}$ ). The process for fractionation was centrifugation samples $(10 \mathrm{mg} / \mathrm{ml})$ at $3,000 \mathrm{xg}$ at $4^{\circ} \mathrm{C}$ for $30 \mathrm{~min}$. Fractionated samples were tested for anti-inflammatory and anti-allergic activities at concentration of $100 \mu \mathrm{g} / \mathrm{ml}$.

\section{Determination of total protein content}

Protein content was measured according to the Lowry method [26] using bovine serum albumin (BSA) as a standard. 


\section{Amino acid composition}

The amino acid profile was determined using High Performance Liquid chromatography (HPLC) according to the method of Hagen et al. [27] with slightly modification. Samples were hydrolyzed with $6 \mathrm{~N} \mathrm{HCl}$ for $24 \mathrm{~h}$ at $100{ }^{\circ} \mathrm{C}$ and the release of amino acids phenylisothiocyanate (PITC). The derivatives were separated on a RP C18 LUNA column (catalog number 00G-4252EQ; $100 \AA$; particle size $5 \mu \mathrm{m}, 250 \times 4.6 \mathrm{~mm}$ i.d.; Phenomenex, Torrance, CA, USA) at $50{ }^{\circ} \mathrm{C}$ and a binary eluant system consisting of (A) $60 \mathrm{mM}$ sodium acetate buffer in triethylamine and (B) acetonitrile in water with EDTA. The UV spectrum was obtained at $254 \mathrm{~nm}$. Quantification was carried out by comparison with a standard mixture (Thermo Scientific, Rockford IL, USA) and DL-2- aminobutyric acid was used as an internal standard from Sigma (St. Louis, MO).

\section{Determination of anti-inflammatory activity}

Anti-inflammatory activity of samples was evaluated in cell culture system using inhibitory effect on nitric oxide (NO) production by murine macrophage-like RAW264.7 cells using a modified method from that which was previously reported [28]. Briefly, the RAW264.7 cell line (purchased from Cell Lines Services) was cultured in RPMI medium supplemented with $0.1 \%$ sodium bicarbonate and $2 \mathrm{mM}$ glutamine, penicillin $\mathrm{G}$ (100 units $/ \mathrm{ml})$, streptomycin $(100 \mu \mathrm{g} / \mathrm{ml})$ and $10 \%$ FCS. The cells were harvested with trypsin-EDTA and diluted to a suspension in a fresh medium. The cells were seeded in 96-well plates with $1 \times 10^{5}$ cells/well and allowed to adhere for $1 \mathrm{~h}$ at $37^{\circ} \mathrm{C}$ in a humidified atmosphere containing $5 \% \mathrm{CO}_{2}$. After that the medium was replaced with a fresh medium containing $1 \mu \mathrm{g} / \mathrm{ml}$ of LPS together with the test samples at various concentrations $(10-500 \mu \mathrm{g} / \mathrm{ml})$ and was then incubated for $24 \mathrm{~h}$. NO production was determined by measuring the accumulation of nitrite in the culture supernatant using the Griess reagent. The Absorbance was measured with a microplate reader at $570 \mathrm{~nm}$. The 1-NA (NO synthase inhibitor) was used as positive controls. The stock solution of each test sample was dissolved in deionized distilled water. Inhibition $(\%)$ was calculated using the following equation and $\mathrm{IC}_{50}$ values were determined graphically $(n=4)$ :

$$
\text { Inhibition }(\%)=\frac{(\mathrm{A}-\mathrm{B}) \times 100}{(\mathrm{~A}-\mathrm{C})}
$$

$A-C: \mathrm{NO}_{2}-$ concentration $(\mu \mathrm{g} / \mathrm{ml})[A$ : LPS $(+)$, sample $(-) ; B$ : LPS (+), sample (+); $C$ : LPS (-); sample (-)].

\section{Determination of pro-inflammatory cytokines in LPS-induced RAW264.7 macrophages}

The levels of TNF- $\alpha$, IL-1 $\beta$, and IL- 6 released into the culture medium were quantified using ELISA Development Kits ((Peprotech, Inc., Rocky Hill, NJ, USA) according to the manufacturer's instructions. Absorbances of TNF- $\alpha$, IL-1 $\beta$, and IL- 6 were measured at $405 \mathrm{~nm}$ with a microplate reader. The absorbance values were then converted to concentrations of TNF$\alpha$, IL-1 $\beta$ and IL-6 using standard curves prepared with serial dilutions of TNF- $\alpha$, IL-1 $\beta$ and IL-6 standards. 


\section{Determination of anti-allergy activity}

The anti-allergy activity of samples was evaluated in a cell culture system using inhibitory effect on the release of $\beta$-HEX from RBL-2H3 cells with a modified method different from that which was previously reported [29]. Briefly, RBL-2H3 cells (purchased from American Type Culture Collection (ATCC)) was dispensed in 24-well plates at a concentration of $2 \times 10^{5}$ cells/well using MEM containing 10\% FCS, penicillin (100 units/ml), streptomycin (100 units/ml) and anti-DNP-IgE $(0.45 \mu \mathrm{g} / \mathrm{ml})$, then incubated overnight at $37^{\circ} \mathrm{C}$ in $5 \% \mathrm{CO}_{2}$ for sensitization of the cells. The cells were washed twice with $500 \mu \mathrm{l}$ of Siraganian buffer $(119 \mathrm{mM} \mathrm{NaCl}, 5 \mathrm{mM} \mathrm{KCl}$, $5.6 \mathrm{mM}$ glucose, $0.4 \mathrm{mM} \mathrm{MgCl}_{2}, 1 \mathrm{mM} \mathrm{CaCl}_{2}, 25 \mathrm{mM}$ piperazine-N,N'-bis(2-ethanesulfonic acid) (PIPES), $0.1 \%$ bovine serum albumin (BSA) and $40 \mathrm{mM} \mathrm{NaOH}, \mathrm{pH} 7.2$ ) and then incubated in $160 \mu \mathrm{l}$ of Siraganian buffer for an additional $10 \mathrm{~min}$ at $37{ }^{\circ} \mathrm{C}$. Afterwards, $20 \mu \mathrm{l}$ of test sample solution was added to each well and incubated for $10 \mathrm{~min}$, followed by the addition of $20 \mu \mathrm{l}$ of antigen (DNP-BSA, final concentration is $10 \mu \mathrm{g} / \mathrm{ml}$ ) at $37{ }^{\circ} \mathrm{C}$ for $20 \mathrm{~min}$ to stimulate the cells to degranulate. The supernatant was transferred into a 96-well plate and incubated with $50 \mu$ of substrate ( $1 \mathrm{mM} p$-nitrophenyl- $N$-acetyl- $\beta$ - $d$-glucosaminide) in $0.1 \mathrm{M}$ citrate buffer ( $\mathrm{pH}$ 4.5) at $37{ }^{\circ} \mathrm{C}$ for $1 \mathrm{hr}$. The reaction was stopped by adding $200 \mu \mathrm{l}$ of stop solution $(0.1 \mathrm{M}$ $\mathrm{Na}_{2} \mathrm{CO}_{3} / \mathrm{NaHCO}_{3}, \mathrm{pH} 10.0$ ). The absorbance was measured with a microplate reader at $405 \mathrm{~nm}$. Ketotifen fumarate was used as positive controls. The test samples were dissolved in deionized distills water, and the solutions were added to Siraganian buffer. Inhibition (\%) of the release of $\beta$-HEX by the test sample was calculated using the following equation and $\mathrm{IC}_{50}$ values were determined graphically $(n=4)$ :

$$
\text { Inhibition }(\%)=\left(\frac{1-(\mathrm{T}-\mathrm{B}-\mathrm{N})}{\mathrm{C}-\mathrm{N}}\right) \times 100
$$

Where: Control (C): DNP-BSA (+) and test sample (-); test (T): DNP-BSA (+) and test sample $(+)$; blank (B): DNP-BSA $(-)$ and test sample $(+)$; normal $(\mathrm{N})$ : DNP-BSA $(-)$ and test sample $(-)$.

\section{Cytotoxicity assessment}

Cytotoxicity was determined using the MTT colorimetric method. Briefly, after $48 \mathrm{~h}$ incubation with the test samples, MTT solution $(10 \mu \mathrm{l}, 5 \mathrm{mg} / \mathrm{ml}$ in PBS) was added to the wells. After $4 \mathrm{~h}$ incubation, the medium was removed and isopropanol containing $0.04 \mathrm{M} \mathrm{HCl}$ was then added to dissolve the formazan production in the cells. The optical density of the formazan solution was measured with a microplate reader at $570 \mathrm{~nm}$. The test compounds were considered cytotoxic when the optical density of the sample-treated group was less than $80 \%$ of that in the control (vehicle-treated) group. The test samples were considered cytotoxic [30-31].

\section{Statistical Analysis}

Data were subjected to Analysis of Variance (ANOVA) and by Duncan's Multiple Range Test [32]. The SPSS statistics program (Version 16.0) was used for data analysis. Statistical significance was tested at $p<0.05$. 


\section{RESULTS AND DISCUSSION}

\section{Anti-inflammatory effect of tuna dark muscle hydrolysates in LPS-induced RAW264.7 macrophage cells}

In RAW264.7 macrophage cell (using MTT assay), cytotoxicity of tuna dark muscle hydrolysates were found to exhibit no cytotoxic effects (>80\% cell viability) at concentrations up to $500 \mu \mathrm{g} / \mathrm{ml}$ (Figure 1A, 1C) compared to the control group [30]. No difference in cell viability between Alcalase and Flavourzyme hydrolysates $(\mathrm{p} \geq 0.05)$ at corresponding concentrations and types and levels of enzyme used. Thus, concentrations $0-500 \mu \mathrm{g} / \mathrm{ml}$ of the tuna dark muscle and its hydrolysates were used throughout the study in order to assess potential anti-inflammatory activity in RAW264.7 macrophage cell.

NO is produced by inducible nitric oxide synthase (iNOS), and has a wide and pervasive regulatory role in the inflammatory response in macrophage cells [33]. Thus, it is fundamentally important to investigate the ability to inhibit the production of NO in macrophages. Potential inhibitors of LPS-induced iNOS may stand a good chance for effectively preventing inflammatory reactions and diseases [33]. Hydrolyzed tuna dark muscle effects on NO production is depicted in Figure 2, indicating $\mathrm{IC}_{50}$ significantly decreases about 5-folds from the un-hydrolyzed controls level to a symptotic level. IC $_{50}$ slightly varied in the intermediate period of hydrolysis (time between 30-120 mins) but all levelled off at relatively similar levels. The asymptotic (end point) level for dark muscle was approximately $60 \mu \mathrm{g} / \mathrm{ml}$ for Alcalase dark muscle and $100 \mu \mathrm{g} / \mathrm{ml}$ for Flavourzyme dark muscle. Alcalase hydrolysates were more effective in NO inhibition activity than Flavourzyme hydrolysates at a given enzyme concentration and hydrolysis time. The lowest $\mathrm{IC}_{50}$ of Alcalase hydrolysates $(51.69 \mu \mathrm{g} / \mathrm{ml}, 2 \%$ enzyme concentration for $240 \mathrm{~min}$ ) was about three-folds concentration lower than Trolox (154.07 $\mu \mathrm{g} / \mathrm{ml})$ and one-fold concentration lower than ascorbic acid $(71.56 \mu \mathrm{g} / \mathrm{ml})$ but higher than LNitroarginine $(14.82 \mu \mathrm{g} / \mathrm{ml})$, which is known as a specific NO synthase inhibitor. The $\mathrm{IC}_{50}$ of Flavourzyme hydrolysate at $2 \%$ enzyme concentration for $240 \mathrm{~min}(81.09 \mu \mathrm{g} / \mathrm{ml})$ was about twofolds concentration lower than Trolox $(154.07 \mu \mathrm{g} / \mathrm{ml})$ and similarly to that of ascorbic acid (71.56 $\mu \mathrm{g} / \mathrm{ml})$. Therefore, it can be concluded that tuna dark muscle hydrolysates exhibited beneficial anti-inflammatory effect and both enzymes use (Alcalase and Flavourzyme) were effective in reducing the inflammation.

ROS generally functions as second messengers in MAPK, PI3K, and NF- $\kappa \mathrm{B}$ signaling pathways, which play a key role in inflammation [34-35]. Therefore, the anti-inflammatory activity of these tuna dark muscle hydrolysates may be due to their antioxidant properties [11], suggesting that NO inhibition was a result of an antioxidative electron transport in the macrophage cells. Antioxidant activity of bioactive peptide related to their amino acid composition and amino acid sequence in the peptide chain. The greatest antioxidant activity in Alcalase by-products hydrolysates may be due to higher amounts of hydrophobic and aromatic amino acid $(p<0.05)$ (Table 1). Consequently, the strongest anti-inflammatory activity of Alcalase by-products hydrolysates was observed (Figure 2). Additionally, higher antioxidant

activity was observed in dark muscle hydrolysate [11]. This result may be due to the high quantity of natural antioxidants in dark muscle like anserine and carnosine [36] (Figure 2). More fundamental studies about specific peptides and other factors of this phenomena are warranted. 

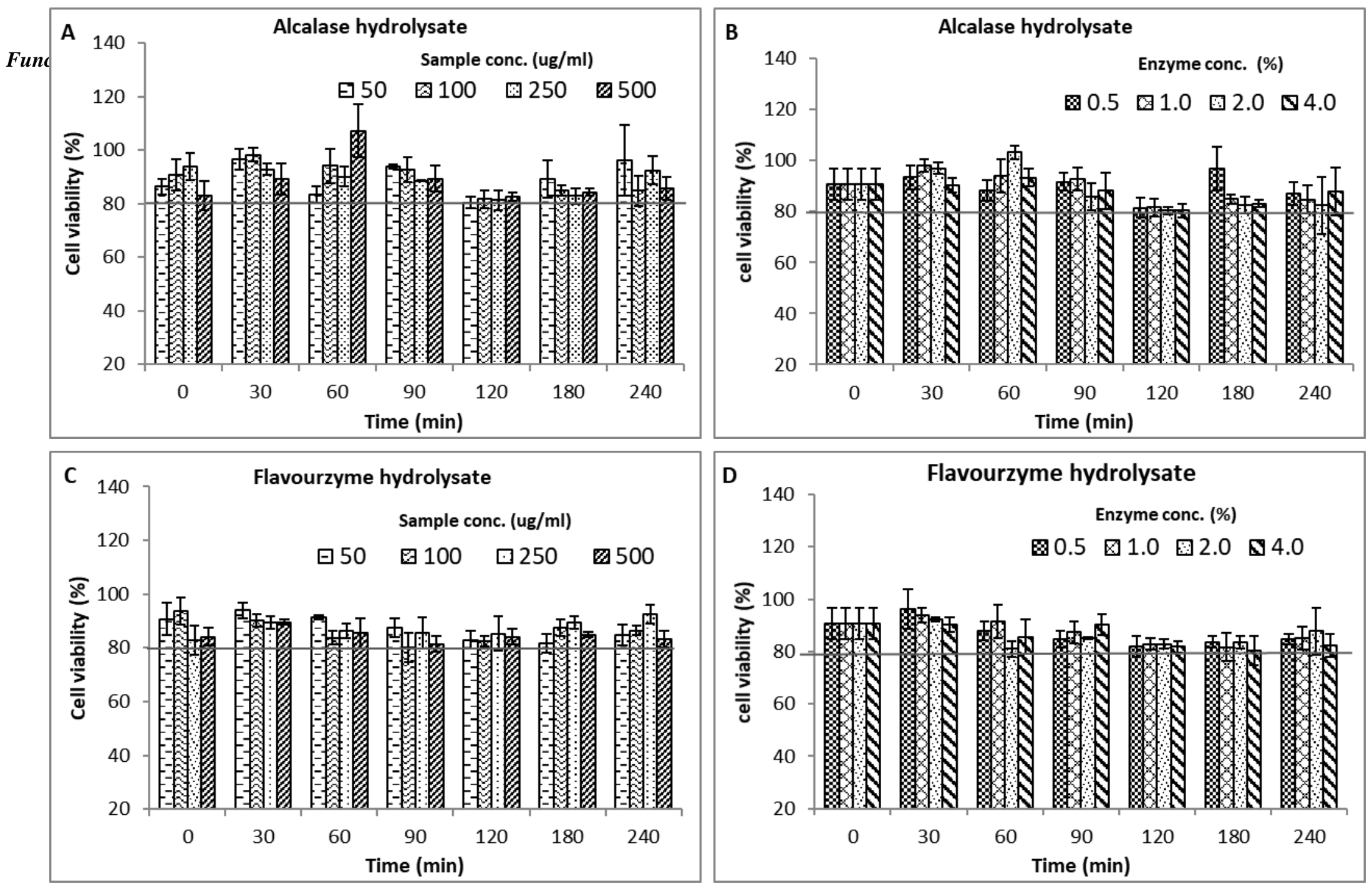

Figure 1. RAW264.7 macrophage cell viabilities following exposure to tuna dark muscle hydrolysates (A) Effect of samples concentration treated with $1 \%$ Alcalase (B) Effect of Alcalase concentration treated with sample $100 \mu \mathrm{g} / \mathrm{ml}$ (C) Effect of samples concentration treated with $1 \%$ Flavourzyme (B) Effect of Flavourzyme concentration treated with sample $100 \mu \mathrm{g} / \mathrm{ml}$ 

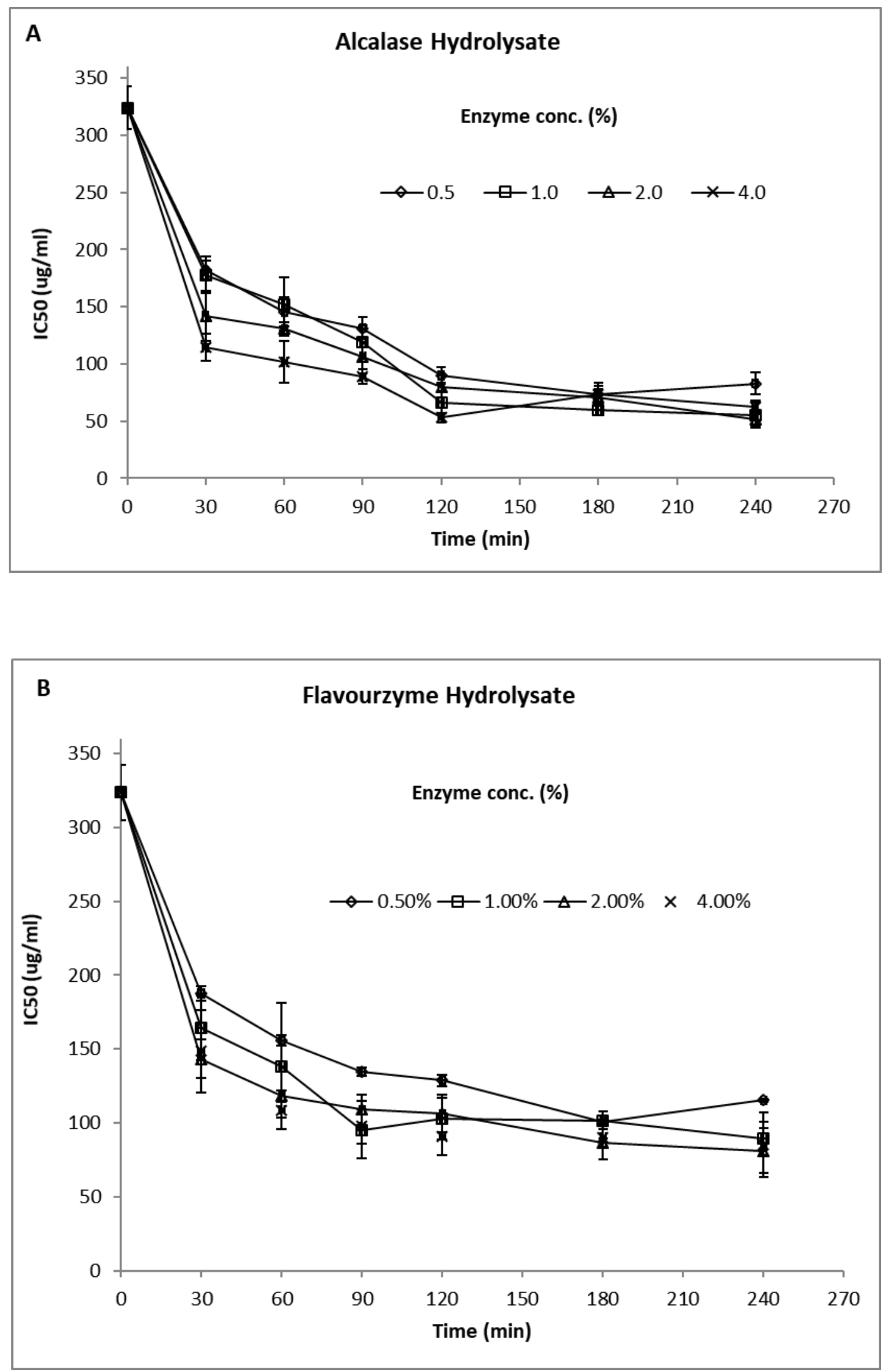

Figure 2. Hydrolysis time dependent of $\mathrm{IC}_{50}$ on NO inhibition of dark muscle tuna hydrolyzed (A) Alcalase and (B) Flavourzyme 
Table 1. Amino acid composition of tuna by-products hydrolysate (1\% enzyme concentration, $240 \mathrm{~min}$ )

\begin{tabular}{|c|c|c|}
\hline \multirow{2}{*}{$\begin{array}{l}\text { Amino acid } \\
\text { (\% in dry basis) }\end{array}$} & \multicolumn{2}{|c|}{ Dark muscle hydrolysate } \\
\hline & Alcalase & Flavourzyme \\
\hline Alanine & $7.93 \pm 0.15$ & $7.36 \pm 0.01$ \\
\hline Arginine & $5.89 \pm 0.02$ & $4.19 \pm 0.02$ \\
\hline Aspartic acid & $10.68 \pm 0.19$ & $10.70 \pm 0.01$ \\
\hline Glutamic acid & $12.34 \pm 0.38$ & $12.16 \pm 0.09$ \\
\hline Glycine & $7.16 \pm 0.06$ & $6.96 \pm 0.01$ \\
\hline Histidine & $6.84 \pm 0.03$ & $6.70 \pm 0.06$ \\
\hline Hydroxyproline & $5.45 \pm 0.06$ & $5.74 \pm 0.02$ \\
\hline Isoleucine & $5.20 \pm 0.11$ & $4.64 \pm 0.02$ \\
\hline Leucine & $9.49 \pm 0.04$ & $8.52 \pm 0.03$ \\
\hline Lysine & $4.05 \pm 0.03$ & $2.87 \pm 0.03$ \\
\hline Methionine & $4.12 \pm 0.02$ & $4.18 \pm 0.06$ \\
\hline Phenylalanine & $3.85 \pm 0.08$ & $3.58 \pm 0.01$ \\
\hline Proline & $3.63 \pm 0.01$ & $3.56 \pm 0.03$ \\
\hline Serine & $6.36 \pm 0.16$ & $6.52 \pm 0.13$ \\
\hline Threonine & $3.49 \pm 0.06$ & $3.27 \pm 0.01$ \\
\hline Tyrosine & $2.80 \pm 0.01$ & $2.27 \pm 0.05$ \\
\hline Valine & $7.37 \pm 0.06$ & $6.68 \pm 0.06$ \\
\hline$\Sigma$ Hydrophobic amino acid* & $44.63 \pm 0.02^{b}$ & $41.30 \pm 0.01^{a}$ \\
\hline$\Sigma$ Aromatic amino acid** & $6.65 \pm 0.07^{\mathrm{a}}$ & $5.85 \pm 0.06^{b}$ \\
\hline
\end{tabular}

*Hydrophobic amino acid refers to Alanine, Glycine, Isoleucine, Leucine, Phenylalanine, Proline and Valine. **Aromatic amino acid refers to Phenylalanine, Tryptophan, and Tyrosine. Different letters in the same row exhibited significant difference at $\mathrm{p}<0.05$.

Molecular weight fraction of tuna dark muscle hydrolysates and their anti-inflammatory activity

Hydrolysates from $1 \%$ enzyme concentration were fractionated according to size by membrane filtration. Each molecular size range was tested for NO inhibitory effect. Protein contents in each fraction (Figure 3) suggested that the increase in smallest peptides fraction ( $<3 \mathrm{KDa}$ ) increased most obviously with hydrolysis time. This was more noticeable in Alcalase hydrolysate and in Flavourzyme hydrolysate. Anti-inflammatory activity of fractionated hydrolysates is shown in Figure 4. NO inhibition of $<3 \mathrm{KDa}, 3-10 \mathrm{KDa}, 10-30 \mathrm{KDa}$, and $>30 \mathrm{KDa}$ fractions are generally 
higher than unfractionated hydrolysate $(\mathrm{p}<0.05)$. An earlier study also reported that NO inhibition was more extensive by fractionated hydrolysates of Mytilus Edulis than unfractionated samples [37]. Ko and Jeon [38] demonstrated that the anti-inflammatory activity of the fractionated samples from Styela clave flesh hydrolysate was also better than the unfractionated one. In this study, at a given time the $<3 \mathrm{KDa}$ fraction from both enzymes exhibited higher NO inhibition than other fractions $(\mathrm{p}<0.05)$, strongly suggesting that small peptide or amino acids were more effective in anti-inflammatory effect (Figure 4). This may be due to the fact that more extensive hydrolysis produces smaller peptides (Figure 3) and that their greater anti-oxidative ability raised the NO inhibition response [11].
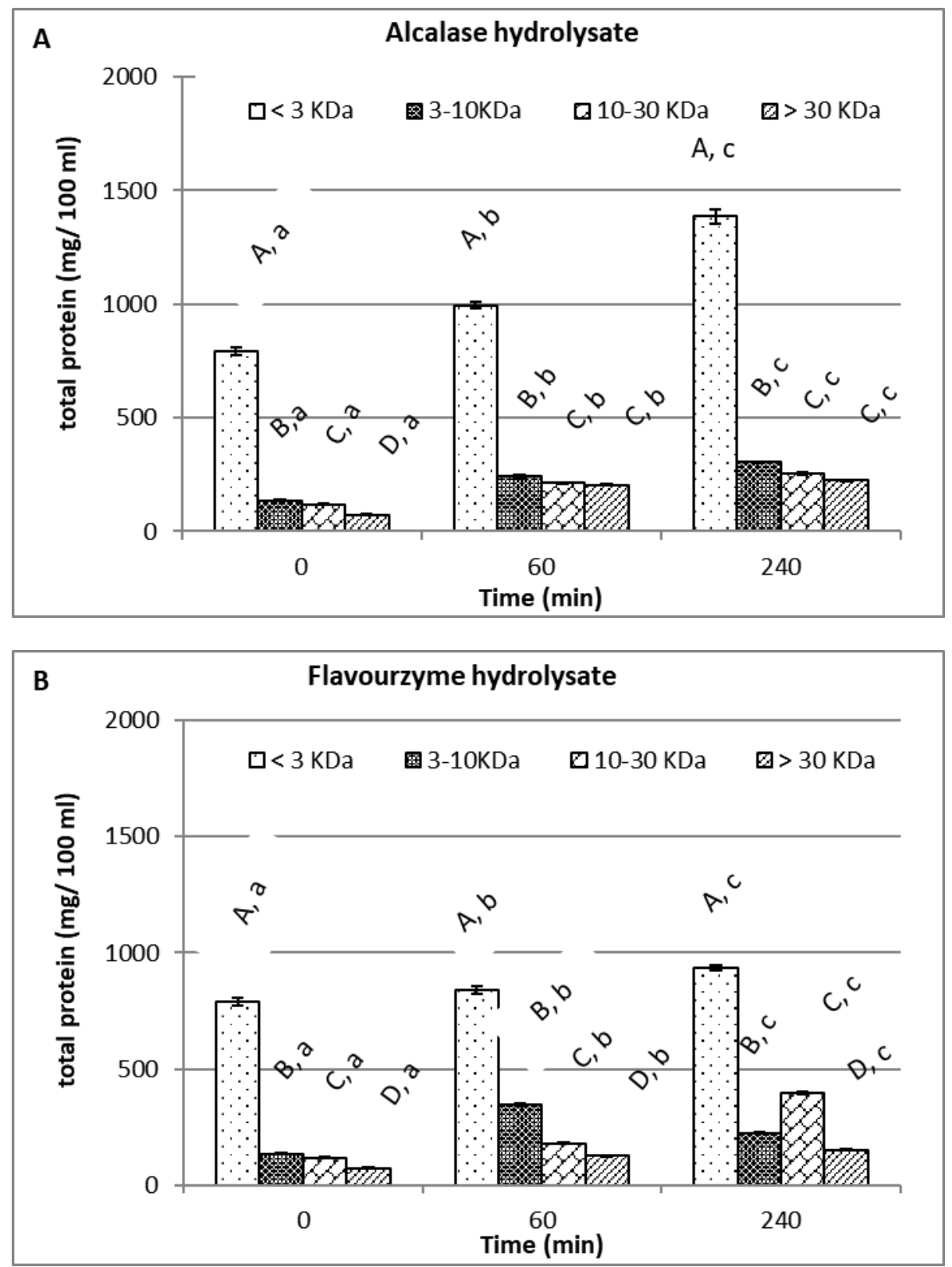

Figure 3. Total protein content of fractionated dark muscle (A) Alcalase hydrolysates and (B) Flavourzyme hydrolysates respectively (Different capital letter in the same hydrolysis time and different small letter in molecular weight exhibited significant different at $\mathrm{p}<0.05$ ) 

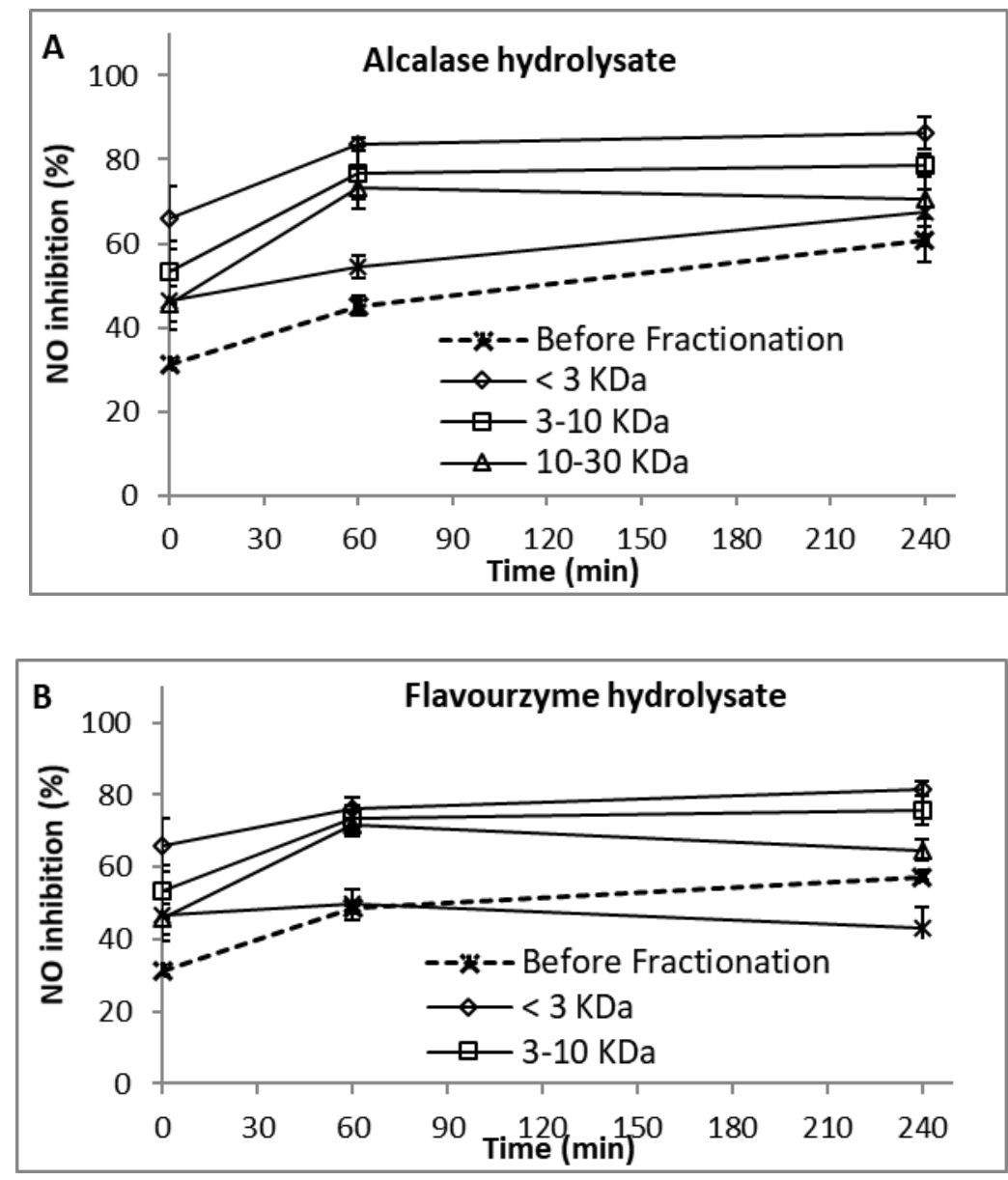

Figure 4. NO inhibition of fractionated hydrolyzed samples (by ultrafiltration) with MWCO at $3 \mathrm{KDa}, 10$ $\mathrm{KDa}$ and $30 \mathrm{KDa}(\mathrm{A})$ Alcalase (B) Flavourzyme (at 1\% enzyme concentration) over 240 min hydrolysis

Additionally, anti-inflammatory activities have also been reported for sweetfish enzymatic hydrolysate [18] and salmon by-product hydrolysate [19]. $\mathrm{PGE}_{2}$, pro-inflammatory cytokines, has been shown that their mRNA expression could be mediated by a down regulation of COX-2, iNOS, ERK-1/2, and NF-KB [18-19]. In this study, relevant inflammatory factors have been shown to be attenuated with hydrolysate by reducing secretion of pro-inflammatory cytokine (TNF- $\alpha$, IL-6 and IL-1 $\beta)$ as shown in Figure 5, indicating that lower MW $(<3 \mathrm{kDa})$ exhibiting greater anti-inflammatory response $(p<0.05)$. Our data presented that dark muscle hydrolysates effectively and significantly inhibited secretion of TNF- $\alpha$; particularly Alcalase hydrolysate that rendered $42 \%$ reduction (Figure 5A). TNF- $\alpha$ is a potent activator of macrophages and can stimulate the production or expression of IL-6, IL-1 $\beta$, PGE2, collagenase, and adhesion molecules. It elicits a number of physiological effects, including septic shock, inflammation, and cytotoxicity [39]. Because of their important roles in inflammatory responses, down-regulation of these pro-inflammatory cytokines is the most important during anti-inflammatory therapy. In this study, we demonstrated that dark muscle hydrolysates inhibited the LPS-induced production of TNF- $\alpha$, IL-1 $\beta$, and IL- 6 . Alcalase hydrolysate samples can greatly reduce secretion of TNF- $\alpha$, IL-6, and IL-1 $\beta$ than Flavourzyme hydrolysate samples (Figure 5) indicating stronger antiinflammatory response of Alcalase hydrolysate samples was observed in result of NO inhibition (Figure 4). 

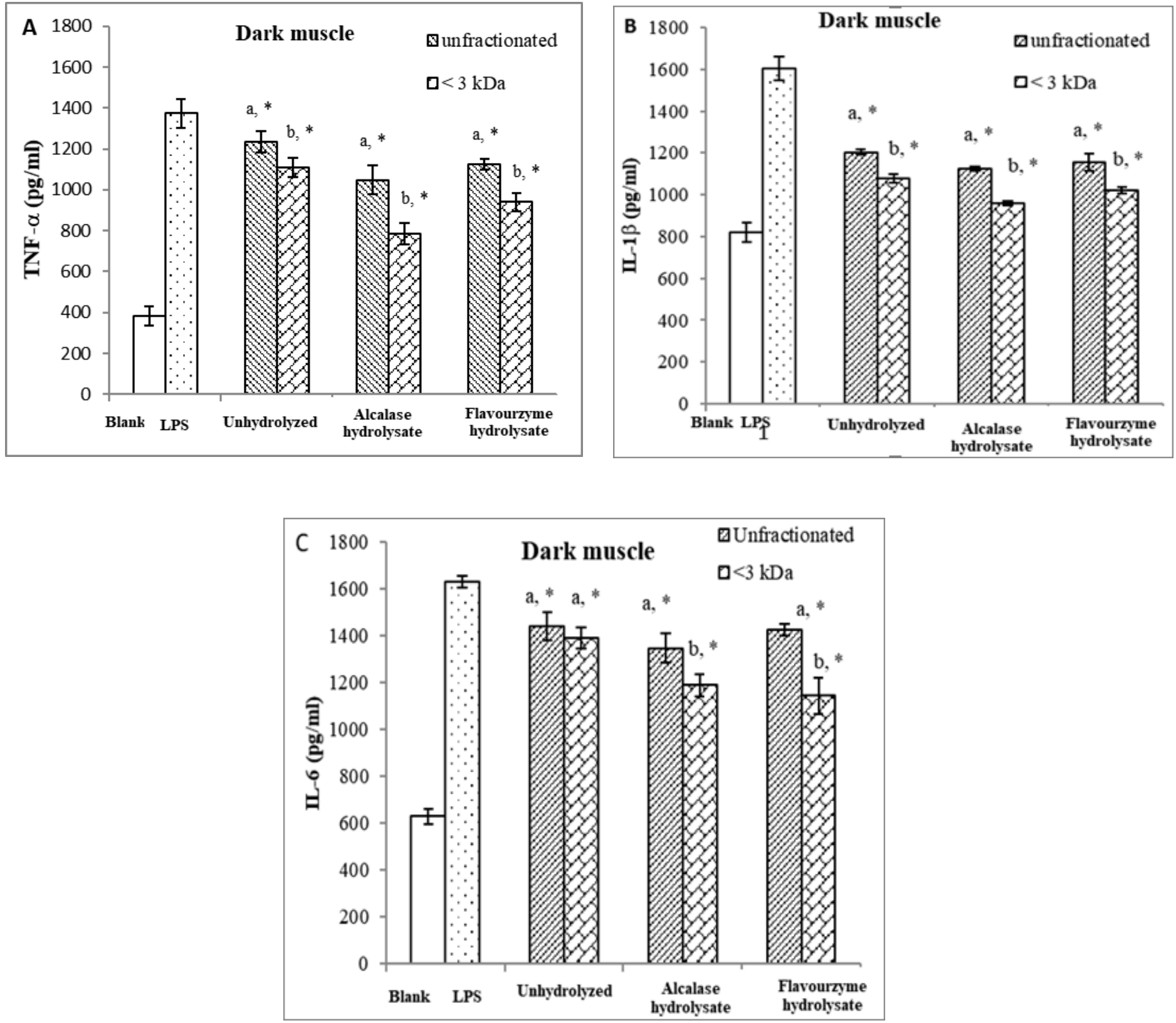

Figure 5. Effect of fractionation (from $1 \%$ enzyme concentration for 240 min hydrolysis at concentration of $100 \mu \mathrm{g} / \mathrm{ml}$ ) of tuna dark muscle on pro-inflammatory cytokines in LPS-induced RAW264.7 macrophages (A) TNF- $\alpha$, (B) IL-1 $\beta$, and (C) IL-6. (* depicts significant difference when compared with LPS-treated sample; Different small letter in the same treated group exhibited significant difference at $\mathrm{p}<0.05$ )

\section{Anti-allergy activity of tuna by-products hydrolysates}

Similarly, to prior toxicity evaluation, cytotoxicity of tuna dark muscle hydrolysates in RBL-2H3 cells using MTT assay demonstrate no cytotoxic effects on RBL-2H3 cells at the levels studied $(0-800 \mu \mathrm{g} / \mathrm{ml})$ from viability results (Figure 6$)$. No difference $(\mathrm{p} \geq 0.05)$ in cell viability between Alcalase and Flavourzyme hydrolysates. Thus, these concentrations $(0-800 \mu \mathrm{g} / \mathrm{ml})$ were used in the anti-allergy activity study in RBL-2H3 cells (Figure 6). 

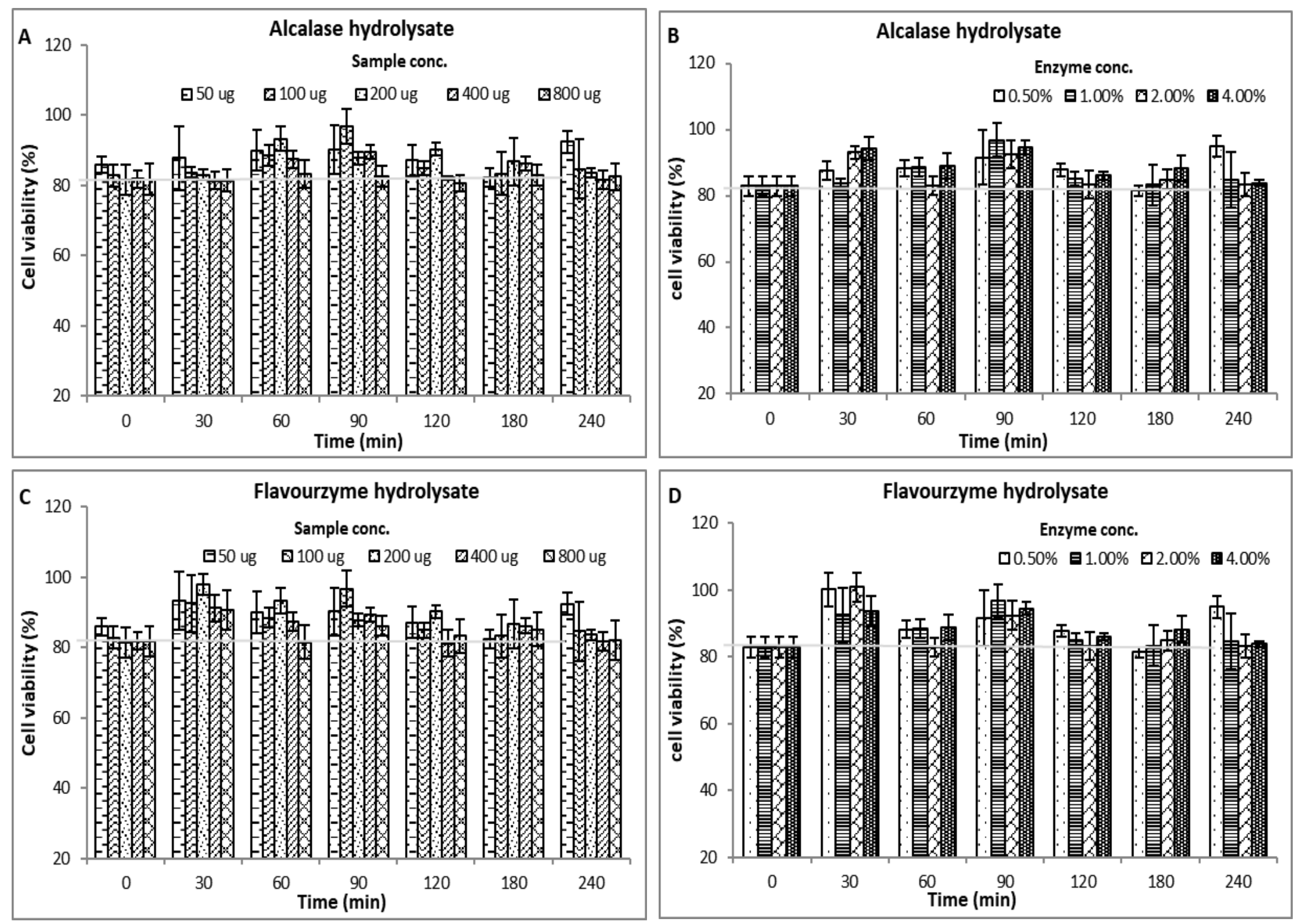

Figure 6. RBL-2H3 cell viabilities following exposure to tuna dark muscle hydrolysates (A) Effect of samples concentration treated with $1 \%$ Alcalase (B) Effect of Alcalase concentration treated with $100 \mu \mathrm{g} / \mathrm{ml}$ sample (C) Effect of samples concentration treated with $1 \%$ Flavourzyme (B) Effect of Flavourzyme concentration treated with $100 \mu \mathrm{g} / \mathrm{ml}$ sample. 
Bioactivity of the hydrolysates was further tested for inhibitory effects of $\beta$-HEX release from IgE-sensitized BSA stimulated RBL-2H3 cells at the antigen-antibody stage. DNP-IgEsensitized RBL-2H3 cells were treated with tuna dark muscle hydrolysates $(50-800 \mu \mathrm{g} / \mathrm{ml})$. All hydrolysates demonstrated significant inhibition of antigen-induced degranulation compared with the un-hydrolyzed sample (Figure 7). The inhibition was discovered to increase with enzyme concentration and hydrolysis time. $\mathrm{IC}_{50}$ of un-hydrolyzed control $(500$ and $600 \mu \mathrm{g} / \mathrm{ml})$ was at its highest compared with all the hydrolyzed samples. This decrease in $\mathrm{IC}_{50}$ with hydrolysis time was steeper up to $60 \mathrm{~min}$ and then decreased more slowly afterwards (Figure 7). The $\mathrm{IC}_{50}$ of all samples was higher than the $\mathrm{IC}_{50}$ of an anti-allergic drug, Ketotifen Fumarate, (at $21.29 \mu \mathrm{g} / \mathrm{ml})$. Alcalase hydrolysates showed a significantly greater inhibition of $\beta$-HEX release than Flavourzyme hydrolysates of a same enzyme concentration and hydrolysis time in both byproducts. Dark muscle hydrolysis with $1 \%$ Alcalase concentration was shown to exhibit $\mathrm{IC}_{50}$ of $65.23 \mu \mathrm{g} / \mathrm{ml}$ (180 min, Figure 7A).

The ability of hydrolysate samples to inhibit $\beta$-HEX release might be due to competitive binding against IgE at Fab fragment region through non-covalent bonds, such as electrostatic interactions, hydrogen bonds, Van der Waals forces, and hydrophobic interaction [40]. Therefore, hydrolysates and BSA (both being proteins) can compete in such interaction with IgE at Fab fragment region. Inter-molecular interaction between hydrolysate molecule and BSA was also a possibility.
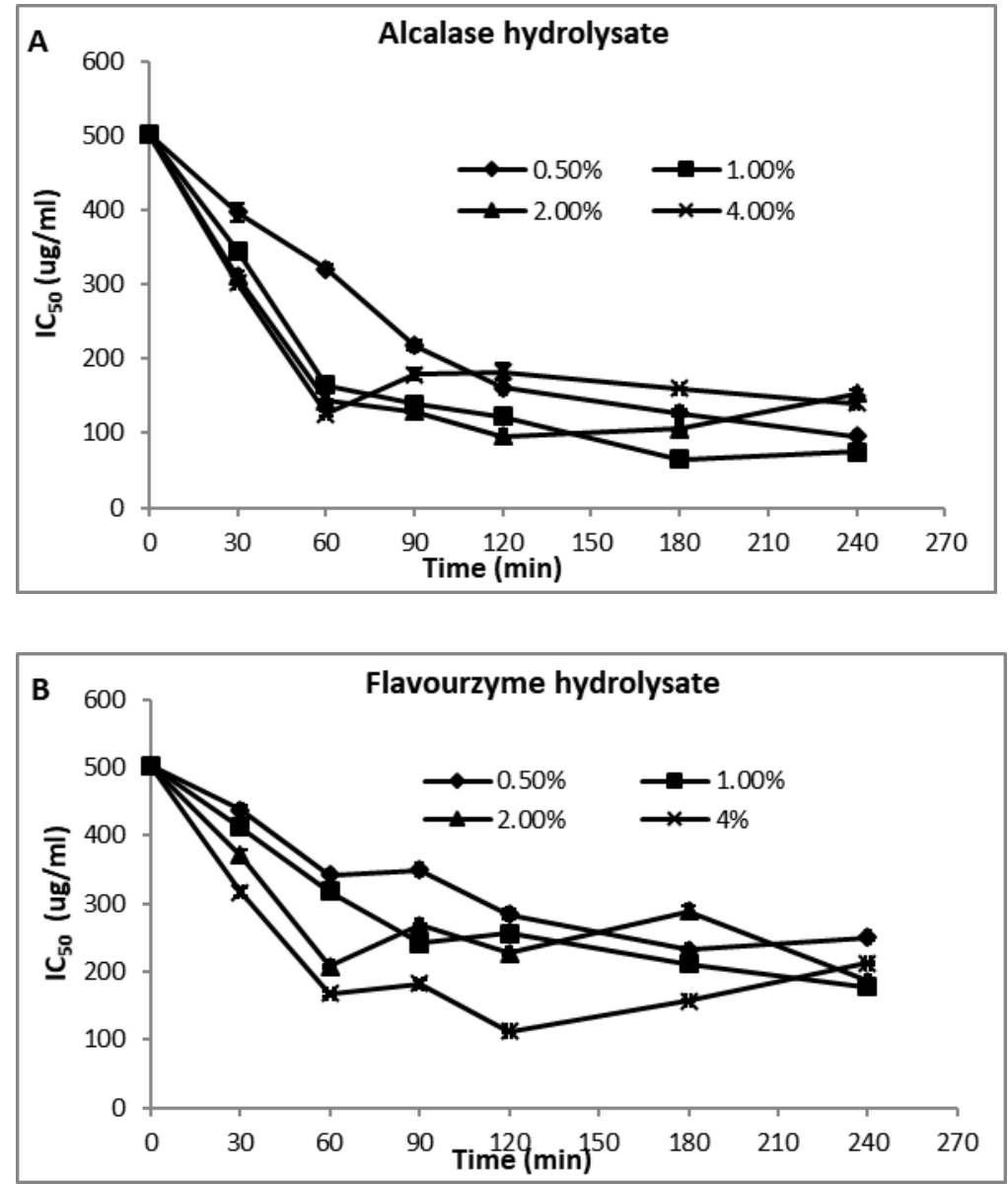

Figure 7. Hydrolysis time dependent of $\mathrm{IC}_{50}$ on anti-allergy activity (A) Alcalase hydrolyzed and (B) Flavourzyme hydrolyzed dark muscle 


\section{Effect of fractionated of tuna by-products hydrolysates on anti-allergy activity}

Selected hydrolysates (1\% enzyme concentration, at $240 \mathrm{~min}$ ) were fractionated according to size by membrane filtration and each molecular size range was tested for anti-allergy activity. The hydrolysates fractionated by ultrafiltration membrane into $<3 \mathrm{KDa}, 3-10 \mathrm{KDa}, 10-30 \mathrm{KDa}$ and $>30 \mathrm{KDa}$, were tested against $\beta$-HEX release. The results are shown in Figure 8 that only < $3 \mathrm{KDa}$ samples exhibited higher inhibitory effect than the un-fractionated with a higher $\beta$-HEX release inhibition of Alcalase hydrolysate at $78 \%$ inhibition (240 min, Figure 8A). This result was similar with previous report demonstrating that hydrolysates with low molecular weight (less than $3 \mathrm{kDa}$ ) from Spirulina maxima exhibited the most inhibition on histamine release from mast cell [41]. Alcalase hydrolysates were found to be more effective than Flavourzyme hydrolysates. In particular, $<3 \mathrm{KDa}$ fractions were found most anti-allergenic (Figure 7). Evidently, histamine release from mast cells is related to cell-membrane permeability [42]. Since peptides with lower molecular weights have a greater tendency to permeate through the cell membrane than higher molecular weight peptides, free amino acids and peptides with $<3 \mathrm{kDa}$ has significant ability to inhibit $\beta$-HEX release. Moreover, this could be due to protein content consisting in each fraction. Low molecular weight fraction contained more protein by weight than higher molecular weight fractions (Figure 3) but in the results are normalized by protein content of all samples.

Earlier study reported that NO selectively enhances the stimulation of Th2 cells but not Th1 cells [43] and IgE-mediated food allergy is typically associated with the dominance of Th2 cells. Therefore, anti-allergy activity of tuna dark muscle hydrolysates might be related to their antiinflammatory activity (Figure 2 and 4). Additionally, in the amino acid composition of lower MW fraction $(<3 \mathrm{kDa}$ ) there was higher amount of hydrophobic and aromatic amino acid observed in Alcalase hydrolyzed samples compared to Flavouzyme hydrolyzed samples (Table 1). Hydrophobic and aromatic amino acids have been reported to play a key role in antioxidative properties that may be a part of reducing $\beta$-HEX secretion $[5,11$, and 43].
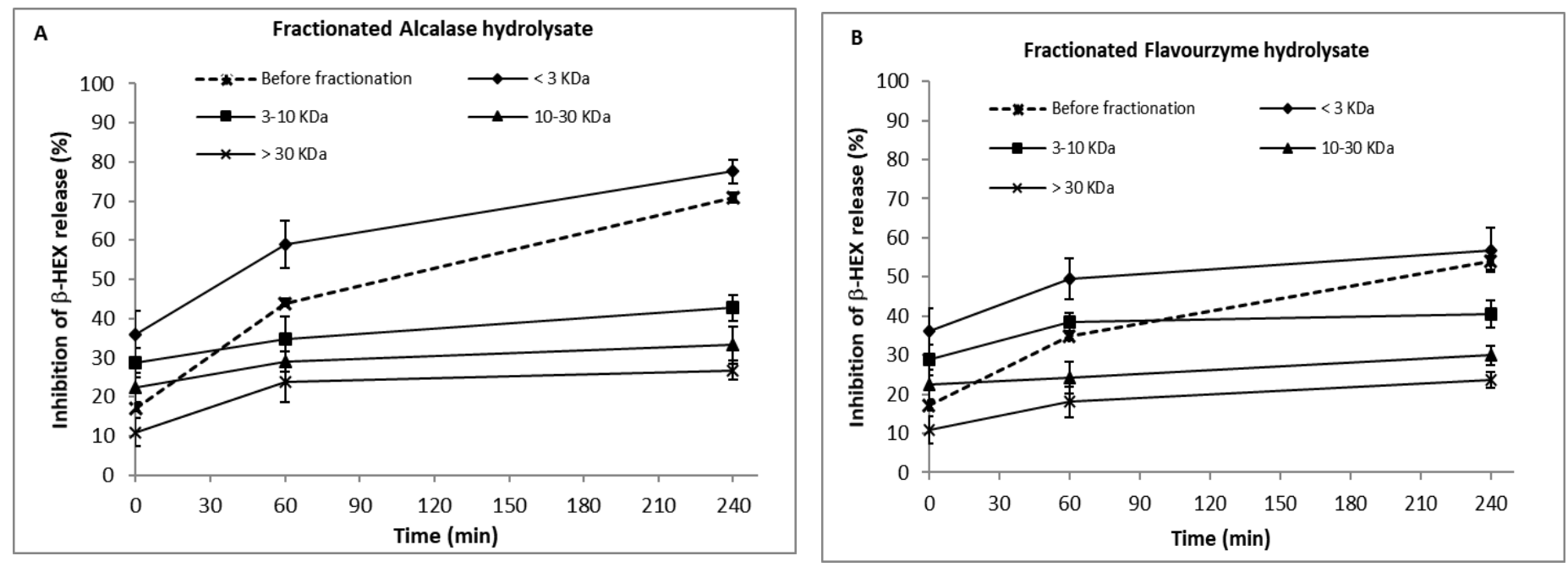

Figure 8. Anti-allergy activity of fractionated hydrolyzed samples (by ultrafiltration) <3 KDa, 3$10 \mathrm{KDa}, 10-30 \mathrm{KDa}$ and $>30 \mathrm{KDa}$ (A) Alcalase Hydrolysate (B) Flavourzyme Hydrolysate at $240 \mathrm{~min}$ hydrolysis and $1 \%$ enzyme concentration. 


\section{CONCLUSION}

Skipjack tuna dark muscle hydrolysates from Alcalase and Flavourzyme resulted in peptides with anti-inflammation activity as determined by NO production in LPS-stimulated RAW 264.7 macrophage cells and anti-allergic properties as measured by a suppression of degranulation of sensitized RBL-2H3 cells. $\mathrm{IC}_{50}$ for $\mathrm{NO}$ inhibition was lowest at $45.44 \mu \mathrm{g} / \mathrm{ml}$ (from $1 \%$ Alcalase, 240 min hydrolysis time) and $\mathrm{IC}_{50}$ for $\beta$-HEX release inhibition was lowest at $65.23 \mu \mathrm{g} / \mathrm{ml}$ (from $1 \%$ Alcalase, 180 min hydrolysis time) quite comparable to known positive substances. Peptide of lowest molecular weight range $(<3 \mathrm{KDa})$ demonstrated the highest anti-inflammatory and anti-allergic actions. Anti-inflammatory effect could be linked to anti-oxidative property and inhibition of $\beta$-HEX release by peptides may be due to membrane-stabilizing action or/and blockade of IgE antibody at fragment region. These results suggested that tuna dark muscle hydrolysates could be further developed into functional foods/ ingredient for anti-inflammatory and anti-allergic related diseases.

List of Abbreviations: NCD, Non-communicable disease; NO, Nitric oxide; LPS, Lipopolyscacharide; $\beta$-HEX, $\beta$-hexosaminadase; TNF- $\alpha$, Tumor necrosis factor- $\alpha$; IL-6, Interleukin 6; IL-1 $\beta$; Interleukin 1 $\beta$; IgE, Immunoglobulin E; MEM, Minimum essential medium eagle (MEM); MTT, 3-(4,5-dimethyl-2-thiazolyl)-2,5-diphenyl-2H-tetrazolium bromide (MTT); 1-NA, 1-nitroarginine; HCl, Hydrochloric acid; MWCO, Molecular weight cut off.

Competing Interests: There are no conflicts of interest to declare.

Author's Contributions: Worrapanit Chansuwan, Chutha Takahashi Upunqui and Pavinee Chinachoti designed the research; Worrapanit Chansuwan performed the research and draft manuscript; Worrapanit Chansuwan, Chutha Takahashi Upunqui and Pavinee Chinachoti analyzed the data. Pavinee Chinachoti edited the manuscript and had primary responsibility for the final content. All authors read and approved the final version of the manuscript.

Acknowledgements and Funding: This research was supported by a grant from the National Research University Project of Thailand's Office of the Higher Education Commission. We thank to Songkla Canning Public Co., Ltd. (Songkhla, Thailand) for providing the raw materials.

\section{REFERENCES}

1. Vijayalakshmi A, Ravichandiran V, Velraj M, Hemalatha S, Sudharani G, Jayakumari S: Antianaphylactic and anti-inflammatory activities of a bioactive alkaloid from the root bark of Plumeria acutifolia Poir. Asian Pac J Trop Biomed 2011, 1(5):401- 405.

2. Paschapur MS, Patil MB, Kumar R, Patil SR: Evaluation of anti-inflammatory activity of ethanolic extract of Borassus flabellifer L. male flowers (inflorescences) in experimental animals. J Med Plants Res 2009, 3(2):49-54.

3. Guastadisegni C, Nicolini A, Balduzzi M, Ajmone-Cat MA, Minghetti L: Modulation of PGE (2) and TNF alpha by nitric oxide in resting and LPS-activated raw 264.7 cells. Cytokine 2002, 19(4):175-180. 
4. Cho YS, Lee SH, Kim SK, Ahn CB, Je JY: Aminoethyl-chitosan inhibits LPS-induced inflammatory mediators, iNOS and COX-2 expression in RAW264.7 mouse macrophages. Process Biochem 2011, 46(2):465-470.

5. Wu D, Meydani SN: Antioxidants and immune function. In Antioxidant Status, Diet, Nutrition and Health. Edited by Papas AM. New York: CRC Press; 1998:371-400.

6. Bougatef A, Nedjar-Arroume N, Manni L, Ravallec R, Barkia A, Guillochon D, Nasri $\mathrm{M}$ : Purification and identification of novel antioxidant peptides from enzymatic hydrolysates of sardinelle (Sardinella aurita) by-products proteins. Food Chem 2011, 118(3):559-565.

7. Hsu KC: Purification of antioxidative peptides prepared from enzymatic hydrolysates of tuna dark muscle by-product. Food Chem 2010, 122(1):42-48.

8. You L, Zhao M, Liu RH, Regenstein JM: Antioxidant and antiproliferative activities of Loach (Misgurnus anguillicaudatus) peptides prepared by papain digestion. J Agric Food Chem 2011, 59(14):7948-7953.

9. Nazeer RA, Kumar NS, Jai GR: In vitro and in vivo studies on the antioxidant activity of fish peptide isolated from the croaker (Otolithes ruber) muscle protein hydrolysate. Peptides 2012, 35(2):261-268.

10. Saidi S, Deratani A, Belleville MP, Amar RB: Antioxidant properties of peptide fractions from tuna dark muscle protein by-product hydrolysate produced by membrane fractionation process. Food Res Int 2014, 65:329-336.

11. Chansuwan W, Chinachoti P: Antioxidative properties and hydrolysis profile of Skipjack tuna (Katsuwonus pelamis) dark muscle and skin. Int Food Res J 2015, 22(5):1968-1976.

12. Beale KM, Laflamme DP: Comparison of a hydrolyzed soy protein diet containing corn starch with a positive and negative control diet in corn- or soy-sensitive dogs [abstract]. Vet Dermatol 2001, 12:237.

13. Cordle CT, Mahmoud MI, Moore V: Immunogenicity evaluation of protein hydrolysate for hypoallergenic infant formulas. J Pediatr Gastroenterol Nutr 1991, 13(3):270-276.

14. Host A, Halken S: Hypoallergenic formulas-when, to whom and how long: after more than 15 years we know the right indication. Allergy 2004, 59(Suppl 78):45-52.

15. Jackson HA, Jackson MW, Coblentz L, Hammerberg B: Evaluation of the clinical and allergen specific serum immunoglobulin E responses to oral challenge with cornstarch, corn, soy and a soy hydrolysate diet in dogs with spontaneous food allergy. Vet Dermatol 2003, 14(4):181-7.

16. Puigdemont A, Brazis P, Serra M, Fondati A: Immunologic responses against hydrolyzed soy protein in dogs with experimentally induced soy hypersensitivity. Am J Vet Res 2006, 67(3):484-8.

17. Ricci R, Jackson HA, Paps JS, Hammerberg B: The magnitude of the clinical response to oral proteins in dogs with spontaneous chicken allergy is significantly reduced when the protein is hydrolyzed [abstract]. Vet Dermatol 2006, 17:210. 
18. Sung NY, Jung PM, Yoon M, Kim JS, Choi JI, Jeong G, Lee JW, et al.: Antiinflammatory effect of sweetfish-derived protein and its enzymatic hydrolysate on LPS-induced RAW 264.7 cells via inhibition of NF-кB transcription. Fish Sci 2012, 78(2):381-390.

19. Ahn CB, Je JY, Cho YS: Antioxidant and anti-inflammatory peptide fraction from salmon by-product protein hydrolysates by peptic hydrolysis. Food Res Int 2012, 49(1):92-98.

20. Parolini C, Vik R, Busnelli M, Bjorndal B, Holm S, Bratteli T, Manzini S, et al.: A salmon protein hydrolysate exerts lipid-independent anti-atherosclerotic activity in ApoE-deficient mice. PLoS ONE 2014, 9(5):e97598.

21. Miyake M, Guillotreau P, Sun CH, Ishimura G: Recent developments in the tuna industry: stocks, fisheries, management, processing, trade and markets. FAO Fisheries Aquacult Tech Paper 2010, 543.

22. Arason S: Utilization of fish by-products in Iceland. In Advances in seafood byproducts: 2002 Conference Proceedings: 2003; Alaska. Edited by Bechtel PJ. Alaska Sea Grant College Program; 2003:43-62.

23. Sanchez-Zapata E, Perez-Alvarez JA: The color in different fish species. Alimentacion, Equipos y Tecnologia 2007, 219:39-43.

24. Karunarathna KAAU, Attygalle MVE: Nutritional evaluation in five species of tuna. Vidyodaya Journal of Science 2010, 15(1-2):7-16.

25. Ovissipour M, Benjakul S, Safari R, Motamedzadegan A: Fish protein hydrolysates production from yellowfin tuna Thunnus albacores head using Alcalase and Protamex. International Aquatic Research 2010, 2:87-95.

26. Lowry OH, Rosebrough NJ, Farr AL, Randall RJ: Protein measurement with the Folin phenol reagent. J of Biol Chem 1951, 193(1):264-275.

27. Hagen SR, Frost B, Augustin J: Precolumn phenylisothiocyanate derivatization and liquid chromatography of amino acids in food. J Assoc Off Anal Chem 1989, 72(6):912-916

28. Banskota AH, Tezuka Y, Nguyen NT, Awale S, Nobukawa T, Kadota S: DPPH radical scavenging and nitric oxide inhibitory activities of the constituents from the wood of Taxus yunnanensis. Planta Med 2003, 69(6):500-505.

29. Matsuda H, Tewtrakul S, Morikawa T, Nakamura A, Yoshikawa M: Anti-allergic principles from Thai zedoary: Structural requirements of curcuminoids for inhibition of degranulation and effect on the release of TNF- $\alpha$ and IL-4 in RBL-2H3 cells. Bioorg Med Chem 2004, 12(22):5891-5898.

30. Matsuda H, Morikawa T, Ando S, Toguchida I, Yoshikawa M: Structural requirements of flavonoids for nitric oxide production inhibitory activity and mechanism of action. Bioorg Med Chem 2003, 11(9):1995-2000.

31. Sae-Wong C, Matsuda H, Tewtrakul S, Tansakul P, Nakamura S, Nomura Y, Yoshikawa M: Suppressive effect of methoxyflavonoids isolated from Kaempferia parviflora on inducible nitric oxide synthase (iNOS) expression in RAW 264.7 cells. J Ethopharmacol 2011, 136(3):488.495. 
32. Steel RG, Torrie JH: Principles and Procedures of Statistic: A Biometrical approach. New York: McGraw-Hill 1980.

33. Chang YC, Li PC, Chen BC, Chang MS, Wang JL, Chiu WT, Lin CH: Lipoteichoic acid-induced nitric oxide synthase expression in RAW264.7 macrophages is mediated by cyclooxygenase-2, prostaglandin E2, protein kinase A, p38 MAPK, and nuclear factor- $\kappa$ B pathways. Cell Signal 2006, 18(8):1235-1243.

34. Chiurchiu V, Maccarrone M: Chronic inflammatory disorders and their redox control: From molecular mechanisms to therapeutic opportunities. Antioxid Redox Sign 2011, 15(9):2605-2641.

35. Srivastava SK, Yadav UC, Reddy AB, Saxena A, Tammali R, Shoeb M, Ansari NH, et al.: Aldose reductase inhibition suppresses oxidative stress induced inflammatory disorders. Chem Biol Interact 2011, 191(1-3):330-338.

36. Ikeda S: Other organic components and inorganic components. In Advances in Fish Science and Technology: Papers Presented at the Jubilee Conference of the Torry Research Station: 23-27 July 1979; Aberdeen, Scotland. Edited by Connell JJ. Fishing News Books 1980:111-124.

37. Park SY, Ahn CB, Je JY: Antioxidant and anti-inflammatory activities of protein hydrolysates from Mytilus Edulis and ultrafiltration membrane fractions. $\mathrm{J}$ of Food Biochem 2014, 38(5):460-468.

38. Ko SC, Jeon YJ: Anti-inflammatory effect of enzymatic hydrolysates from Styela clave flesh tissue in lipopolysaccharide-stimulated RAW 264.7 macrophages and in vivo zebrafish model. Nutri Res Prac 2015, 9(3):219-226.

39. Kim KN, Heo SJ, Yoon WJ, Kang SM, Ahn G, Yi TH, Jeon YJ: Fucoxanthin inhibits the inflammatory response by suppressing the activation of NF- $\kappa \mathrm{B}$ and MAPKs in lipopolysaccharide-induced RAW 264.7 macrophages. Eur J Pharmacol 2010, 649(13):369-375.

40. Janeway CA Jr, Travers P, Walport M, Shlomchik MJ: Immunobiology: The Immune System in Health and Disease. 5th edition. New York: Garland Science 2001.

41. Vo TS, Ryub B, Kim SK: Purification of novel anti-inflammatory peptides from enzymatic hydrolysate of the edible microalgal Spirulina maxima. J Funct Food 2013, 5(3):1336-1346.

42. Dahlquist R, Diamant B, Kruger PG: Increased permeability of the rat mast cell membrane to sodium and potassium caused by extracellular ATP and its relationship to histamine release. Int Arch Allergy Appl Immunol 1974, 46(5):655-675.

43. Niedbala W, Cai B, Liew FY: Role of nitric oxide in the regulation of $\mathrm{T}$ cell functions. Annals of the Rheumatic Diseases 2006, 65(Suppl 3):37-40. 